\title{
FAKTOR-FAKTOR YANG MEMPENGARUHI CAPITAL ADEQUACY RATIO (CAR) BANK UMUM SYARIAH DI INDONESIA ${ }^{1]}$
}

\author{
Yeano Dwi Andhika \\ Mahasiswa Program Studi Ekonomi Islam-Fakultas Ekonomi dan Bisnis-Universitas Airlangga \\ Email: yeano.dwi-12@feb.unair.ac.id
}

Noven Suprayogi

Departemen Ekonomi Syariah-Fakultas Ekonomi dan Bisnis-Universitas Airlangga

Email: noven.suprayogi@feb.unair.ac.id

\begin{abstract}
:
Capital adequacy regulation imposed on banks, including Islamic banks, is part of the regulators' efforts to ensure that banks have adequate capital in order to get them prepared facing the risks that might arise in their operations. This research aims to find the effects of Islamic banks' specific variables on Capital Adequacy Ratio (CAR), the capital adequacy indicator in banks.

Using panel data regression, this research investigates the possible effects of four bank spesific variables which are Bank Size (LNSIZE), Non-Performing Financing (NPF), Return on Equity (ROE), and Financing to Deposit Ratio (FDR) on Capital Adequacy Ratio (CAR). There are 11 Indonesia's Islamic commercial banks during 2011 to 2015 used as sample. As Fixed Effect Model (FEM) chosen to be the estimation model, this research indicates that LNSIZE, NPF, ROE and FDR have significant effects on CAR with different level of significance.

Key Words : Capital Adequacy Ratio, Islamic Commercial Banks, Panel Data Regression
\end{abstract}

\section{PENDAHULUAN}

\section{Latar Belakang}

Perbankan syariah sebagaimana perbankan konvensional merupakan lembaga intermediasi yang menghimpun dana dari masyarakat untuk kemudian disalurkan kembali kepada masyarakat. Dalam proses intermediasi ini perbankan menghadapi berbagai macam risiko seperti risiko gagal bayar, risiko likuiditas, dan berbagai risiko lainnya. Berbagai regulasi perbankan yang diterbitkan, sebagaimana dijelaskan oleh Imam Wahyudi dkk (2013:38) adalah dalam rangka memastikan usaha perbankan bisa berjalan dengan hati-hati (prudent) mengingat dampak risiko-risiko tersebut bisa sangat fatal bagi perbankan.

Salah satu aspek dalam perbankan yang selama ini mendapat perhatian para pembuat kebijakan adalah aspek kecukupan modal (capital adequacy). Masalah permodalan ini menjadi penting sebagaimana disampaikan Siamat (2004:100) terkait dengan fungsi pokoknya yaitu memberikan perlindungan kepada setiap nasabah jika bank mengalami kerugian di luar jumlah yang diperkirakan sebelumnya. Modal bank dengan demikian menjadi salah satu aspek penting bagi bank untuk bisa memperoleh kepercayaan dari masyarakat selain juga seperti yang disampaikan Muhammad (2002:102) bahwa modal juga penting bagi bank untuk mendukung rencana ekspansi. Capital Adequacy Ratio (CAR) seperti yang disebutkan Rivai dkk (2013:465) menjadi indikator apakah 
sebuah bank telah cukup memiliki modal dan cadangan untuk memikul berbagai risiko yang mungkin akan timbul.

Regulasi Basel menjadi regulasi utama yang bersifat global mengenai kecukupan modal bank dalam tiga dekade terakhir dan telah diadopsi oleh banyak yurisdiksi di dunia. Saat ini Basel III menjadi regulasi mutakhir yang telah mulai diimplementasikan sejak 2013 dan diharapkan sudah bisa diterapkan secara penuh oleh yurisdiksi yang mengadopsinya pada tahun 2019. Persoalan pentingnya kecukupan modal yang bukan monopoli perbankan konvensional kemudian juga membuat Islamic Financial Services Board (IFSB), badan yang dibentuk guna melakukan harmonisasi regulasi di lembaga keuangan syariah di seluruh dunia juga mengeluarkan regulasi mengenai kecukupan modal bank syariah pada tahun 2005 yang kemudian direvisi pada tahun 2013 (IFSB-15). Aturan mengenai kecukupan modal IFSB pada dasarnya mengacu pada regulasi Basel dengan tambahan-tambahan peraturan khas yang mengatur lembaga keuangan syariah yang tidak diatur dalam regulasi Basel.

Mengingat substansi regulasi Basel III yang kemudian diadopsi dalam peraturan IFSB-15 terkait dengan upaya penguatan permodalan dalam rangka meningkatkan ketahanan perbankan terhadap krisis, perbankan syariah berkepentingan untuk memastikan bahwa ke depan mereka mampu memiliki kerangka permodalan yang kuat dan stabil.

Dalam rangka mewujudkan permodalan yang kuat dan stabil tersebut, perbankan syariah harus memperbaiki kinerja terutama terkait variabel-variabel yang sekiranya mampu mendorong upaya optimalisasi CAR yang dimilikinya. Berbagai variabel spesifik perbankan selama ini telah banyak diteliti pengaruhnya terhadap CAR, sayangnya subjek penelitian tersebut kebanyakan adalah bank konvensional.

Di antara sedikit penelitian yang meneliti pengaruh variabel spesifik bank terhadap CAR pada perbankan syariah adalah penelitian yang dilakukan oleh Abusharba dkk (2013). Abusharba dkk meneliti pengaruh Return on Assets (ROA), Non-Performing Financing (NPF), Deposits Structure (DEP), Liquidity (FDR), dan Operating Expenses to Operating Income (OEOI) terhadap CAR pada 11 bank umum syariah selama periode 2009-2011.

Mengingat terbatasnya penelitian mengenai faktor-faktor apa sajakah yang memiliki pengaruh terhadap CAR perbankan syariah di satu sisi dan di sisi lain topik kecukupan modal adalah topik yang juga penting bagi pernguatan perbankan syariah, peneliti kemudian tertarik untuk melakukan penelitian dengan judul "Faktor-Faktor Yang Mempengaruhi Capital Adequacy Ratio (CAR) Bank Umum Syariah (BUS) di Indonesia" yang akan meneliti variabelvariabel spesifik dalam perbankan syariah yang sekiranya memiliki pengaruh 
terhadap CAR. Hasil penelitian ini diharapkan dapat membantu industri perbankan syariah nasional mengoptimalkan kinerjanya pada variabel-variabel yang mampu mendukung optimalisasi CAR yang dimilikinya.

\section{TINJAUAN PUSTAKA}

Muhammad

(2002:209)

menjelaskan bahwa sebagai lembaga yang juga berorientasi pada laba, permodalan yang kuat perlu dimiliki oleh bank syariah untuk menjaga kepercayaan dari nasabahnya. Modal yang kuat juga akan membantu bank syariah untuk mengembangkan dan memajukan bisnisnya ke depan.

Masalah permodalan ini sendiri merupakan salah satu topik pembahasan yang paling penting dalam perbankan. Berbagai usulan reformasi regulasi dalam perbankan, terutama setelah terjadinya krisis 2008 tidak lepas dari upaya peningkatan kuantitas dan kualitas modal yang dimiliki oleh bank (Elliot, 2010).

Fungsi modal bank mengutip Koch dan MacDonald (2003:481) pada dasarnya adalah untuk mengurangi risiko. Hal ini dapat terjadi melalui tiga hal dasar yaitu menjadi bantalan bagi bank untuk menyerap kerugian dan tetap solvent, memberikan akses bank ke pasar keuangan, dan membatasi pertumbuhan bank dan risk-taking.

Manajemen modal yang baik oleh bank syariah mempertimbangkan berbagai hal di atas menjadi sesuatu yang penting dalam rangka memastikan bahwa sebagai entitas bisnis, bank syariah akan tetap stabil dan tidak mudah guncang ketika krisis ekonomi melanda di kemudian hari.

Modal bank secara singkat sebagaimana didefiniskan oleh Taswan (2013:139) adalah dana yang diinvestasikan pemilik dalam rangka pendirian badan usaha yang dimaksudkan untuk membiayai kegiatan usaha bank selain juga untuk memenuhi regulasi yang telah ditetapkan oleh otoritas moneter. Sumber dana bank seperti penjelasan Kasmir (2010:62-63) bisa berasal dari dana bank itu sendiri, masyarakat luas, dan lembaga lain. Sumber dana yang berasal dari bank inilah yang merupakan sumber dana dari modal sendiri yang dapat dikumpulkan melalui setoran modal dari pemegang saham, cadangan-cadangan bank, dan laba bank yang belum dibagi. Terkait sumber modal bank eksternal, Koch dan MacDonald

(2003:489-492) mengklasifikasikannya menjadi empat kelompok yaitu utang subordinasi (subordinated debt), saham biasa (common stock), saham preferen (preferred stock), dan pengaturan sewa (leasing arrangements).

Terkait beberapa sumber modal bank eksternal yang dijelaskan oleh Koch dan MacDonald, tidak keseluruhannya dapat digunakan oleh bank syariah sebagai sumber modal. Muhammad (2015:138-139) menjelaskan dengan mengutip apa yang dikatakan oleh 
Antonio (1999:223) bahwa pinjaman subordinasi tidak dapat dipertimbangkan sebagai modal bank syariah karena sifatnya sebagai qard tidak beralasan jika ikut menanggung risiko dan memberikan proteksi bagi kepentingan deposan. Saham preferen yang memberikan dividen tetap juga mirip seperti bunga sehingga menggunakannya sebagai modal bank syariah juga hal yang tidak bisa dilakukan.

Muhammad menyebut modal bank syariah terdiri dari modal inti (core capital) dan kuasi ekuitas. Modal inti berasal dari para pemilik yang disetor para pemegang saham, cadangan, dan laba ditahan sedangkan kuasi ekuitas merupakan dana-dana yang tercatat dalam rekening bagi hasil (mudharabah). Modal inti memiliki fungsi sebagai penyangga dan penyerap kerugian serta melindungi kepentingan pemegang rekening titipan (wadiah) dan pinjaman (qard), sedangkan kuasi ekuitas hanya dapat menanggung risiko atas aktiva yang dibiayai oleh dana dari rekening bagi hasil itu sendiri setelah terbukti bahwa risiko memang timbul bukan akibat kelalaian pihak manajemen bank sebagai mudharib.

Kerangka perhitungan modal bank sendiri didasarkan atas regulasi Basel yang telah diimplementasikan sejak 1988 diawali dengan implementasu Basel I. Saat ini, Basel III merupakan regulasi Basel paling mutakhir yang dirumuskan setelah terjadinya krisis keuangan 2008 yang membuat banyak bank besar collapse.
Regulasi Basel III ini mulai diimplementasikan pada tahun 2013 dan diharapkan sudah berlaku penuh di yurisdiksi yang mengadopsi Basel III ini pada tahun 2019.

Substansi Basel III ini sendiri sebagaimana yang disebutkan oleh Bank Indonesia dalam Consultative Paper Basel III-nya adalah terkait dengan penguatan kerangka permodalan global yang terdiri dari peningkatan kualitas, konsistensi, dan transparansi

permodalan, pengembangan cakupan risiko, penambahan persyaratan modal berbasis risiko dan leverage ratio, pengurangan procyclicality dan peningkatan countercyclical buffer, serta addressing systemic risk dan keterkaitan antar lembaga keuangan. Substansi yang kedua adalah pengenalan standar likuiditas global yang terdiri dari Liquidity Coverage Ratio (LCR), Net Stable Funding Ratio (NSFR), dan Monitoring Tools.

Tabel 1.

Kerangka Permodalan Basel III

\begin{tabular}{|c|c|c|c|}
\hline \multicolumn{4}{|c|}{$\begin{array}{c}\text { Calibration of the Capital Framework } \\
\text { Capital requirements and buffers (all numbers } \\
\text { in percent) }\end{array}$} \\
\hline & $\begin{array}{c}\text { Common } \\
\text { Equity } \\
\text { (after } \\
\text { deduc- } \\
\text { tions) }\end{array}$ & $\begin{array}{c}\text { Tier 1 } \\
\text { Capital }\end{array}$ & $\begin{array}{c}\text { Tier 2 } \\
\text { Capital }\end{array}$ \\
\hline Minimum & 4.5 & 6.0 & 8.0 \\
\hline $\begin{array}{c}\text { Conservation } \\
\text { buffer }\end{array}$ & 2.5 & & \\
\hline $\begin{array}{c}\text { Minimum plus } \\
\text { conservation } \\
\text { buffer }\end{array}$ & 7.0 & 8.5 & 10.5 \\
\hline $\begin{array}{c}\text { Countercycli- } \\
\text { cal buffer } \\
\text { range }\end{array}$ & $0-2.5$ & & \\
\hline
\end{tabular}

Sumber: Basel Committee on Banking Supervision (2010) 
Implementasi Basel III di Indonesia

sendiri diatur melalui PBI No. 15/12/PBI/2013 tentang Kewajiban Penyediaan Modal Minimum Bank Umum dan kemudian melalui POJK No. 11/POJK.03/2016 yang secara substansi keduanya tidak berbeda. Melalui peraturan tersebut bank akan diwajibkan menyediakan modal minimum sesuai dengan profil risikonya masing-masing serta tambahan modal sebagai penyangga (buffer) yang terdiri dari capital conservation buffer $12,5 \%$ dari ATMR), countercyclical buffer $10 \%-2,5 \%$ dari ATMR), dan capital surcharge untuk Domestic Systematically Important Bank (D-SIB) (1\%-2,5\% dari ATMR).

Tabel 2.

Penyediaan Modal Minimum Sesuai Profil Risiko Bank

\begin{tabular}{|c|c|}
\hline Profil Risiko & $\begin{array}{c}\text { Modal Minimum dari Aktiva } \\
\text { Tertimbang Menurut Risiko } \\
\text { (ATMR) }\end{array}$ \\
\hline I & $8 \%$ \\
\hline II & $9 \%-\leq 10 \%$ \\
\hline III & $10 \%-\leq 11 \%$ \\
\hline IV dan V & $11 \%-\leq 14 \%$ \\
\hline
\end{tabular}

Sumber: PBI No.1 5/12/PBI/2013 (diolah)

Namun demikian terkait dengan besaran persentase countercyclical buffer dan capital surcharge untuk D-SIB, regulator berhak menetapkan kisaran persentase yang berbeda dari apa yang telah ditetapkan di atas menyesuaikan dengan kondisi makroekonomi yang terjadi.

Meskipun penerapan Basel III melalui peraturan $\mathrm{BI}$ dan OJK tersebut lebih dipersiapkan untuk perbankan konvensional, mengingat aturan IFSB tentang penyediaan modal minimum bank syariah (IFSB-15) secara substansi mengadopsi Basel III, maka adopsi regulasi IFSB-15 di Indonesia harusnya juga tidak akan jauh berbeda dengan Basel III.

Terdapat empat variabel spesifik perbankan yang diteliti pengaruhnya terhadap CAR dalam penelitian ini yaitu ukuran bank, non-performing financing, return on equity, dan financing to deposit ratio. Masing-masing variabel tersebut diyakini memiliki pengaruh yang signifikan terhadap CAR.

\section{METODE PENELITIAN}

\section{Pendekatan Penelitian}

Penelitian ini menggunakan pendekatan kuantitatif dengan metode regresi data panel.

\section{Identifikasi Variabel}

Variabel penelitian dibagi menjadi dua yakni variabel dependen dan variabel independen. Terdapat satu variabel independen yakni Capital Adequacy Ratio (CAR) dan empat variabel independen yang terdiri dari ukuran bank (LNSIZE), non-performing financing (NPF), return on equity (ROE), dan financing to deposit ratio (FDR).

\section{Definisi Operasional Variabel}


Tabel 3.

Definisi Operasional Variabel

\begin{tabular}{|c|c|}
\hline $\begin{array}{c}\text { Variabel } \\
\text { Penelitian }\end{array}$ & Definisi Operasional \\
\hline $\begin{array}{c}\text { Capital } \\
\text { Adequacy } \\
\text { Ratio } \\
\text { (CAR) }\end{array}$ & CAR $=\frac{\text { Modal }}{\text { ATMR }} \times 100 \%$ \\
\hline $\begin{array}{c}\text { Ukuran } \\
\text { Bank } \\
\text { (LNSIZE) }\end{array}$ & LNSIZE $=$ LN(Total Aset) \\
\hline $\begin{array}{c}\text { Non- } \\
\text { Performing } \\
\text { Financing } \\
\text { (NPF) }\end{array}$ & NPF Gross \\
\hline $\begin{array}{c}\text { Return on } \\
\text { Equity } \\
\text { ROE) }\end{array}$ & ROE $=\frac{\text { Laba Bersih }}{\text { Ekuitas Biasa }}$ \\
\hline $\begin{array}{c}\text { Financing } \\
\text { to Deposit } \\
\text { Ratio (FDR) }\end{array}$ & FDR $=\frac{\text { Total Pembiayaan }}{\text { Total Dana Pihak Ketiga }}$ \\
\hline
\end{tabular}

\section{Jenis dan Sumber Data}

Jenis data dalam penelitian ini adalah data sekunder yang berasal dari laporan keuangan 11 bank umum syariah (BUS) yang diteliti selama periode 20112015 serta database perbankan OJK.

\section{Teknik Analisis}

Penelitian ini menggunakan metode regresi data panel karena data dalam penelitian ini terdiri dari data cross section dan time series. Setelah pada tahap pertama dilakukan regresi, selanjutnya akan dipilih satu yang terbaik dari tiga model estimasi yang ada yakni Pooled Least Square (PLS), Fixed Effect Model (FEM), dan Random Effect Model (REM).

Uji Chow akan digunakan untuk memilih mana model estimasi terbaik antara PLS dan FEM, jika FEM yang terpilih selanjutnya dilakukan Uji Hausman untuk menentukan mana yang terbaik antara FEM dan REM. Pengujian kriteria statistik juga akan dilakukan untuk mengetahui bagaimana variabel independen berpengaruh terhadap variabel dependen baik secara simultan maupun parsial (menggunakan Uji F-statistik dan tStatistik) serta sejauh mana kemampuan model dalam menerangkan variasi variabel dependen (Koefisien determinasi).

\section{HASIL DAN PEMBAHASAN}

\section{Hasil Regresi Data Panel}

Hasil regresi data panel pada ketiga model estimasi menunjukkan bahwa dua dari empat variabel independen yakni LNSIZE dan FDR memiliki pengaruh signifikan terhadap CAR pada model estimasi PLS pada tingkat signifikansi 10 persen (10\%) yang digunakan dalam penelitian ini. Pada model estimasi FEM, keseluruhan variabel independen berpengaruh signifikan pada tingkat signifikansi 10 persen yang digunakan. Pada model estimasi REM, hanya LNSIZE dan FDR yang memiliki pengaruh signifikan terhadap CAR pada tingkat signifikansi yang digunakan yakni 10 persen, Maka dengan demikian, variabel LNSIZE dan FDR berpengaruh signifikan pada ketiga model estimasi yang ada.

\section{Pemilihan Model Estimasi}

Tabel 4. Hasil Uji Chow

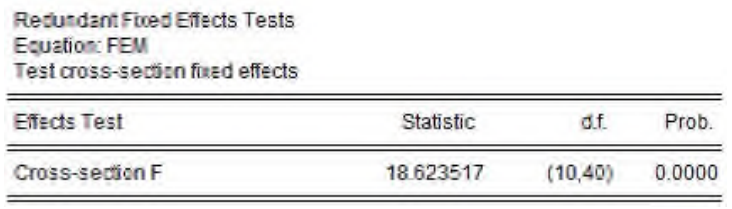

Sumber: Hasil Regresi EViews7 
Hasil Uji Chow menunjukkan bahwa probabilitas cross section $F$ signifikan pada tingkat 10 persen (10\%) yang digunakan dalam penelitian ini sehingga dapat disimpulkan bahwa model estimasi FEM lebih tepat digunakan dalam penelitian ini dibandingkan model estimasi PLS

Tabel 5.

Hasil Uji Hausman

\begin{tabular}{|c|c|c|c|}
\hline \multicolumn{4}{|c|}{$\begin{array}{l}\text { Carrelated Rasdsm Effects - Hausman Test } \\
\text { Equation REII } \\
\text { Test crss-Section random affects }\end{array}$} \\
\hline Test Semmary & Chi-Sq Statistic & Chi-Sq d. & Prob. \\
\hline Corss-section random & 12941877 & 4 & 0.0116 \\
\hline
\end{tabular}

Sumber: Hasil Regresi EViews7

Hasil Uji Hausman menunjukkan bahwa probabilitas Uji Hausman signifikan pada tingkat 10 persen (10\%) yang digunakan dalam penelitian ini sehingga dapat disimpulkan bahwa model estimasi FEM lebih tepat digunakan dalam penelitian ini dibandingkan model estimasi REM.

\section{Uji Statistik}

Berdasarkan Uji F-Statistik, probabilitas F-statistic sebesar 0,000000 atau lebih kecil dari signifikansi yang digunakan (10\%) sehingga dapat disimpulkan bahwa LNSIZE, NPF, ROE, dan FDR secara simultan berpengaruh terhadap CAR, sedangkan berdasarkan Uji t-Statistik pada model estimasi terpilih yakni FEM keseluruhan variabel independen juga signifikan berpengaruh terhadap CAR secara parsial. Koefisien determinasi $\left(R^{2}\right)$ model terpilih juga diperoleh angka sebesar 0,975712 (97,57\%) yang dapat diartikan bahwa variasi dalam variabel CAR 11 BUS di Indonesia dapat dijelaskan sebesar 97,57 persen oleh variasi dalam variabel independennya, sisanya yakni 2,43 persen dipengaruhi oleh variabel lain di dalam model.

Tabel 6.

Hasil Regresi Model Terpilih (FEM)

\begin{tabular}{|c|c|c|c|c|}
\hline Var. & Koef. & Std. Error & $\begin{array}{c}\text { t- } \\
\text { Statistik }\end{array}$ & Prob. \\
\hline Kons. & 148,5242 & 70,27835 & 2,113370 & 0,0409 \\
\hline LNSIZE & $-4,448227$ & 2,372755 & $\begin{array}{c}- \\
1,874710\end{array}$ & 0,0681 \\
\hline NPF & $-0,624620$ & 0,063961 & $\begin{array}{c}- \\
9,765629\end{array}$ & 0,0000 \\
\hline ROE & $-0,113702$ & 0,042024 & - \\
2,705664 & 0,0100 \\
\hline FDR & 0,096811 & 0,016164 & 5,989207 & 0,0000 \\
\hline R2 & & 0,975712 \\
\hline Adj. $\mathbf{R}^{2}$ & \multicolumn{5}{|c|}{0,967211} \\
\hline F-stat. & 114,7784 \\
\hline $\begin{array}{l}\text { Prob. } \\
\text { (F- } \\
\text { stat.) }\end{array}$ & \multicolumn{5}{|c|}{0,000000} \\
\hline
\end{tabular}

\section{Pembahasan}

Keseluruhan variabel independen (empat variabel) yang diteliti pengaruhnya terhadap Capital Adequacy Ratio (CAR), yakni Ukuran bank (LNSIZE), Non-Performing Financing (NPF), Return on Equity (ROE), dan Financing to Deposit Ratio (FDR) dalam model estimasi Fixed Effect memiliki pengaruh signifikan. Ukuran bank, NPF, dan ROE memiliki pengaruh signifikan negatif terhadap CAR sedangkan FDR memiliki pengaruh signifikan positif terhadap CAR.

Pengaruh signifikan dan negatif ukuran bank terhadap CAR dapat diartikan bahwa setiap peningkatan satu persen ukuran bank akan menurunkan 
CAR sebesar 0,044 persen (lin-log model). Pengaruh negatif ukuran bank terhadap CAR ini sesuai dengan penelitian yang dilakukan oleh Raharjo dkk (2014) dan Shaddady dan Moore (2015). Meskipun bank dengan aset besar sebagaimana yang disampaikan Van Greuning dan labal (2008:103) cenderung memiliki profitabilitas yang tinggi sehingga juga memiliki kemampuan meningkatkan modalnya, namun seperti yang dijelaskan oleh Raharjo dkk (2014) bahwa bank dengan ukuran besar juga memiliki kemungkinan untuk memiliki rasio kecukupan modal yang lebih kecil dibandingkan bank-bank yang secara ukuran jauh lebih kecil. Menurut Raharjo dkk peningkatan aset bank umumnya disebabkan oleh kenaikan aset bank yang produktif baik dalam bentuk pembiayaan maupun investasi pada aset-aset yang berisiko. Seiring dengan tumbuhnya pembiayaan dan kepemilikan atas instrumen-instrumen keuangan yang berisiko maka potensi kerugian bank akibat utang yang tidak dibayarkan (bad debts) dan kerugian yang disebabkan oleh turunnya harga instrumen keuangan yang dimiliki oleh bank juga menjadi semakin besar. Sesuai dengan regulasi kecukupan modal bank yang ada, maka tambahan utang yang tidak terbayarkan dan instrumen keuangan yang berisiko tersebut akan menaikkan Risk-Weighted Assets (RWA) bank yang kemudian akan membuat CAR menjadi turun.

Menurut Van Greuning dan labal (2008:160), bank syariah menjadi lebih rentan tergerus modal karena memiliki risiko agak unik dibandingkan bank konvensional terkait dengan kepemilikan investasi berbasis ekuitas, yakni mudharabah dan musyarakah. Meskipun pengawasan yang baik telah dilakukan pada kontrak-kontrak yang berbasis pada skema profit-and-loss-sharing tersebut, kerentanan tergerusnya modal masih lebih besar apabila dibandingkan bank konvensional yang tidak memiliki investasi pada jenis tersebut.

Selain itu, bank-bank dengan ukuran besar sebagaimana disebutkan Raharjo dkk (2014) sering dipandang sebagai bank yang sifatnya "too-big-tofail". Hal tersebut terkait dengan stigma yang berkembang bahwa bank-bank dengan ukuran besar cenderung akan diselamatkan oleh pemerintah ketika akan mengalami kebangkrutan karena memiliki dampak sistematis bagi perekonomian jika sampai mengalami insolvency. Adanya privilege tersebut membuat bank-bank dengan ukuran besar cenderung merasa aman memegang modal yang persentase rasionya lebih kecil jika dibandingkan bank-bank lain yang secara ukuran jauh lebih kecil. Bank-bank kecil ini karena dipandang tidak memiliki risiko sistematis bagi perekonomian jika mengalami kebangkrutan, mau tidak mau mereka harus punya bantalan risiko yang kuat karena tidak mungkin mengandalkan bailout dari pemerintah. Hasil penelitian Ayomi dan Hermanto (2013) yang menyebutkan bahwa semakin besar total 
aset suatu bank semakin besar pula kontribusinya terhadap risiko sistemik mendukung hal tersebut.

Non-Performing Financing (NPF) berpengaruh signifikan dan negatif terhadap CAR. Berdasarkan hasil regresi, setiap kenaikan satu persen pada NPF akan menurunkan CAR sebesar 0,62 persen. Hal ini sesuai dengan teori yang disampaikan oleh Rose dan Hudgins (2005:485-486) bahwa NPF akan merugikan bank karena tingginya NPF pada akhirnya akan mengurangi modal yang dimiliki oleh bank yang bersangkutan. Sebagaimana yang juga diungkapkan oleh Firmansyah (2014) bahwa peningkatan NPF akan meningkatkan jumlah Penyisihan Penghapusan Aset Produktif (PPAP) yang pada akhirnya akan menggerus modal.

Pengaruh signifikan dan negatif NPF terhadap CAR ini sesuai dengan penelitian Abusharba dkk (2013) yang mengatakan bahwa dana tidak tertagih (uncollectable funds) yang tinggi akan secara efektif mengurangi tingkatan minimum CAR yang dimiliki bank. Namun hal ini tidak sesuai dengan penelitian yang dilakukan oleh Raharjo dkk (2014) yang menemukan korelasi positif antara NPF dengan CAR. Menurut Raharjo dkk, adanya potensi peningkatan kerugian akibat adanya pembiayaan bermasalah justru diantisipasi oleh manajemen dengan menaikkan jumlah modal yang dimiliki oleh bank untuk menyerap kerugian (absorb potential losses).
Hasil penelitian ini yang menemukan korelasi negatif antara NPF dan CAR yang berbeda dengan penelitian Raharjo dkk yang menemukan korelasi positif sebenarnya dapat dilihat dari dua sisi. Hasil penelitian ini yang menyatakan bahwa NPF yang naik telah berdampak pada turunnya rasio modal BUS dapat dimaknai sebagai sebuah hubungan kausalitas antara NPF dan CAR. Manajemen BUS yang tidak sigap dalam mengeluarkan kebijakan antisipatif menghadapi kemungkinan naiknya pembiayaan bermasalah di BUS dalam kasus ketika NPF benar-benar naik hingga pada satu titik karena tidak adanya kebijakan antisipatif telah menyebabkan modal tergerus. Di sisi lain, penelitian Raharjo dkk yang menemukan korelasi positif antara NPF dengan CAR pada empat bank BUMN (Mandiri, BRI, BNI, dan BTN) dapat dimaknai bahwa manajemen keempat bank BUMN telah mengeluarkan kebijakan antisipatif ketika melihat adanya indikasi naiknya kredit bermasalah dengan terlebih dahulu menaikkan modal sebagai bantalan risiko, sehingga dengan adanya antisipasi tersebut NPF tidak membuat modal bank menjadi tergerus melainkan justru membuat modal yang dimiliki bank menjadi naik.

Return on Equity (ROE) memiliki pengaruh signifikan dan negatif terhadap CAR, bahwa setiap kenaikan satu persen pada ROE akan menurunkan CAR sebesar 0,11 persen. Hal ini juga sesuai dengan hasil penelitian Nuviyanti dan Anggono (2014) yang memperoleh hasil signifikan 
dan negatif ketika meneliti pengaruh ROE terhadap CAR. Korelasi negatif antara CAR dan ROE ini dapat dijelaskan dengan teori yang disampaikan oleh Siamat (2004:103) bahwa memang terdapat trade-off antara sisi keamanan dan keuntungan bagi pemegang saham bank. Semakin besar jumlah modal yang dimiliki bank semakin rendah ROE-nya. Dalam banyak kasus, ketika bank merasa bahwa modal yang dimilikinya perlu untuk diperkuat mereka akan memilih menggunakan laba ditahan untuk memperkuat modal yang dimilikinya dengan konsekuensi dividen yang diberikan kepada pemegang saham akan turun. Apabila manajemen bank kemudian meyakini bahwa tidak akan timbul kerugian akibat terjadinya pembiayaan bermasalah, sehingga tidak perlu memperkuat bantalan risiko, maka bank akan mengurangi jumlah modal untuk meningkatkan equity multiplier-nya yang pada gilirannya akan meningkatkan ROE.

Financing to Deposit Ratio (FDR) berpengaruh signifikan dan positif terhadap CAR, setiap kenaikan satu persen FDR akan meningkatkan CAR sebesar 0,096 persen. Hal ini sesuai dengan teori yang disampaikan oleh Hempel dan Simonson (1999:323-324) bahwa bank yang memberikan pinjaman secara agresif harus memiliki modal yang lebih banyak dibandingkan bank yang memiliki risiko lebih kecil (kurang agresif dalam menyalurkan pinjaman). Sesuai dengan konsep modal yang salah satu fungsinya adalah sebagai bantalan risiko, maka hasil penelitian ini menunjukkan bahwa 11 BUS yang secara umum bisa dikatakan agresif dalam menyalurkan pembiayaan karena memiliki rata-rata FDR 99,45 persen selama lima tahun periode penelitian telah menyadari bahwa konsekuensi meningkatnya risiko akibat agresifnya mereka dalam menyalurkan pembiayaan adalah dengan penguatan bantalan risiko, yakni dengan menambah modal yang dimilikinya.

Tingginya Loan to Deposit Ratio (LDR), istilah perbankan konvensional untuk menyebut FDR menurut Surjaningsih dkk (2014) mengindikasikan ekspansi kredit bank yang besar dengan sumber dana (funding) yang relatif lebih terbatas sehingga berpotensi menyebabkan bank mengalami kesulitan likuiditas. Apabila dirasa ekspansi kredit bank sudah terlalu tinggi regulator bisa campur tangan melalui kebijakan instrumen permodalan countercyclical capital buffer (CCB). Sebagaimana diketahui bahwa CCB ini merupakan komponen modal khusus yang dibebankan kepada bank untuk mengantisipasi kerugian bila terjadi pertumbuhan kredit yang berlebihan. Maka pembebanan CCB ini pada akhirnya juga akan menambah modal yang dimiliki oleh bank.

\section{SIMPULAN}

Baik secara simultan maupun parsial, keempat variabel independen (LNSIZE, NPF, ROE, dan FDR) berpengaruh 
terhadap CAR, maka dengan demikian LNSIZE, NPF, ROE, dan FDR bisa dikatakan sebagai faktor-faktor yang mempengaruhi CAR pada bank umum syariah (BUS) di Indonesia selama periode 2011-2015. Berkaitan dengan hal tersebut, manajemen BUS harus memperhatikan capaian kinerja keuangannya serta kebijakan korporasi yang dilakukannya seperti pembagian keuntungan terhadap pemegang saham mengingat hal-hal tersebut berpengaruh terhadap upaya optimalisasi CAR dalam rangka mewujudkan kerangka permodalan perbankan syariah yang kuat dan stabil di masa mendatang.

\section{DAFTAR PUSTAKA}

Abusharba, Mohammed T. dkk. 2013. Determinants of Capital Adequacy Ratio (CAR) in Indonesian Islamic Commercial Banks. Global Review of Accounting and Finance Vol. 4 No. 1, March 2013: 159-170

Ayomi, Sri dan Bambang Hermanto. 2013.

Mengukur Risiko Sistemik dan Keterkaitan Finansial Perbankan di Indonesia. Buletin Ekonomi Moneter dan Perbankan Bank Indonesia, Oktober 2013: 103-126

Bank Indonesia. 2013. Peraturan Bank Indonesia No. 15/12/PBI/2013

Departemen Penelitian dan Pengaturan Perbankan. 2012. Consultative Paper Basel III: Global Regulatory Framework for More Resilient Banks and Banking Systems. Jakarta: Bank Indonesia
Elliot, Douglas J. 2010. A Primer on Bank Capital. The Brookings Institution, 28 Januari 2010

Hempel, George S. dan Donald G. Simonson. 1999. Bank Management: Text and Cases. Hoboken, New Jersey: John Wiley and Sons, Inc

IFSB. 2013. Revised Capital Adequacy Standard for Institutions Offering Islamic Financial Services (Excluding Islamic Insurance (Takaful) Institutions and Islamic Collective Investment Schemes

Kasmir. 2010. Dasar-Dasar Perbankan. Jakarta: Rajawali Pers

Koch, Timothy W. dan S. Scott MacDonald. 2003. Bank Management. Fifth Edition. Ohio: South-Western Thomson

Muhammad. 2002. Manajemen Bank Syariah. Yogyakarta: UPP AMP YKPN 2015. Manajemen Dana Bank Syariah. Jakarta: Rajawali Pers Nuviyanti dan Achmad Anggono. 2014. Determinants of Capital Adequacy Ratio (CAR) in 19 Commercial Banks (Case Study: Period 2008-2013). Journal of Business and Management Vol. 3 No. 7, 2014: 752-764

Otoritas Jasa Keuangan. 2016. Peraturan Otoritas Jasa Kevangan No. 11/POJK.03/2016

Raharjo, Pamuji Gesang dkk. 2014. Determinant of Capital Ratio: A Panel Data Analysis on State-Owned Banks in Indonesia. Buletin Ekonomi Moneter dan Perbankan Vol. 16 No.4 April2014: 395-4 14

Rivai, Veithzal dkk. 2013. Commercial Bank Management: Manajemen Perbankan 
dari Teori ke Praktik. Jakarta: Rajawali

Pers

Rose, Peter S. dan Sylvia C. Hudgins. 2005.

Bank Management and Financial Services. Sixth Edition. New York: McGraw-Hill

Shaddady, Ali dan Tom Moore. 2015. Determinants of Capital Adequacy Ratio in Oil Exporting Countries: Evidence from GCC Commercial Banks. Proceedings of the Second Middle East Conference on Global Business, Economics, Finance, and Banking, Dubai 22-24 Mei 2015

Siamat, Dahlan. 2004. Manajemen Lembaga Kevangan. Edisi Empat. Lembaga Penerbit FEUI

Surjaningsih, Ndari dkk. 2014. Early Warning Indicator Risiko Likuiditas Perbankan. Working Paper Bank Indonesia No. 1 Tahun 2014

Taswan. 2013. Akuntansi Perbankan: Transaksi dalam Valuta Rupiah. Edisi Tiga. Yogyakarta: UPP STIM YKPN Van Greuning, Hennie dan Zamir lqbal. 2008. Risk Analysis for Islamic Banks. Washington DC: The World Bank Wahyudi, Imam dkk. 2013. Manajemen Risiko Bank Islam. Jakarta: Salemba Empat 